\title{
Reproduction of Pirapitinga do Sul (Brycon opalinus Cuvier, 1819) in the Parque Estadual da Serra do Mar-Núcleo Santa Virgínia, São Paulo, Brazil
}

\author{
Gomiero, LM.* and Braga, FMS. \\ Departamento de Zoologia, Instituto de Biociências, Universidade Estadual Paulista - UNESP, \\ CP 199, CEP 13506-900, Av. 24-A, n. 1515, Rio Claro, São Paulo, Brazil \\ *e-mail: leanmg@rc.unesp.br \\ Received October 7, 2005 - Accepted April 25, 2006 - Distributed August 31, 2007
}

(With 6 figures)

\begin{abstract}
The objective of the study was to characterize seasonally and locally the reproduction of Pirapitinga do Sul (Brycon opalinus). The study area included three rivers (Paraibuna, Ipiranga, and Grande) in the Santa Virgínia Unit of the Serra do Mar State Park, State of São Paulo, Brazil. Breeding occurred in spring, summer, and autumn. The $L_{50}$ and the $\mathrm{L}_{100}$ of this species were 16 to $18 \mathrm{~cm}$ and 26 to $28 \mathrm{~cm}$, respectively. Spawning was total, with synchronous development in two groups. The size of mature oocytes was $1,346.4 \mu \mathrm{m}$, reaching a maximum of $2,570.4 \mu \mathrm{m}$, with a mean fecundity of 9,190.5 oocytes. This species has external fertilization, is non-migratory, and lacks parental care of the young. Preservation of the Pirapitinga do Sul depends, in great part, on maintaining water quality, preservation of the riverine forests, and access to breeding areas.
\end{abstract}

Keywords: Brycon opalinus, reproduction, fecundity, Brazil.

\section{Reprodução da Pirapitinga do Sul (Brycon opalinus Cuvier, 1819) no Parque Estadual da Serra do Mar-Núcleo Santa Virgínia, São Paulo, Brasil}

\begin{abstract}
Resumo
O objetivo do estudo foi caracterizar sazonalmente e localmente a reprodução da Pirapitinga do Sul (Brycon opalinus). A área de estudo abrangeu três rios (Paraibuna, Ipiranga e Grande) no PESM-Núcleo Santa Virgínia. A época reprodutiva ocorreu na primavera, verão e outono. $\mathrm{O} L_{50}$ e o $L_{100}$ desta espécie foi de 16 a $18 \mathrm{~cm}$ e 26 a $28 \mathrm{~cm}$, respectivamente. A desova foi do tipo total com desenvolvimento sincrônico em dois grupos, e o tamanho dos ovócitos maduros foi de 1.346,4 $\mu \mathrm{m}$ atingindo o máximo em 2.570,4 $\mu \mathrm{m}$, com a fecundidade média de 9.190,5 ovócitos. Esta espécie adequouse à definição de peixes com fecundação externa, não-migradores e sem cuidado parental com a prole. A preservação da Pirapitinga do Sul depende em grande parte da qualidade da água, da preservação das matas ribeirinhas e do acesso às áreas de reprodução.
\end{abstract}

Palavras-chave: Brycon opalinus, reprodução, fecundidade, Brasil.

\section{Introduction}

The State of São Paulo contains the largest remaining area of the Atlantic Forest and associated coastal ecosystems of Brazil, which represent approximately $7 \%$ of the original vegetation cover. A large part of the forest remnants are in state parks, ecological stations, and experimental stations, which occupy more than $3 \%$ of the land area of the state (Villani et al., 1998).

The aquatic resources of the entire Paraíba Valley have been severely impacted since the region began to be occupied by farms during the colonial period. These activities, carried out without due conservation management, led to the cutting of gallery forests, silting of streams, water pollution, and innumerable other environmental problems. In addition to the impacts caused by agricultural and industrial activities, this basin has been affected by the implantation of many reservoirs for electric power generation and/or water storage, among them the Paraibuna and Paraitinga Dam, and the Funil Dam (Hilsdorf and Petrere Jr., 2002).

The characid freshwater fishes of the genus Brycon are typically silver-gray, medium to large in size, and usually important for commercial and subsistence fisheries. The Pirapitinga do Sul, Brycon opalinus (Cuvier, 1819), is in the vulnerable category (IUCN). In the DOU (Diário Oficial da União) of 21 May 2004, the Brazilian Federal government declared this species to be threatened with extinction, and prohibited its fishing or any form of removal, except for purposes of scientific research. 
The Pirapitinga do Sul is endemic in the headwater streams of the Paraíba do Sul basin (Hilsdorf and Petrere Jr., 2002). This basin is located in the extreme northern part of the zone of dense ombrophyle forest in southeastern Brazil, and in general the region has a high percentage of endemic fish species. This high diversity results from the topographic and physiognomic characteristics, which provide a wide range of different environments that favor the occurrence of many species, each of which is adapted to a particular subgroup of these environments, increasing the number of endemisms (Buckup, 2003).

The Pirapitinga do Sul is found in mountainous regions, is adapted to low temperatures (Cidale et al., 2003), and is restricted to the states of Minas Gerais, São Paulo, and Rio de Janeiro (Géry and Mahnert, 1992).

The reproduction of Brycon is typical of fishes which form shoals, moving in schools to breed (piracema), always to favorable areas for the development of larvae and fry (Kramer, 1978a).

Herbivorous fish species which consume fruits and seeds, undergo breeding migration in a restricted time of year, display total spawning by period, lay free eggs that hatch rapidly and whose young are unassisted by the parents, ought to be better observed, because any kind of modification of the hydric system can cause changes in their populations (Barrela et al., 2001; Andrade-Talmelli et al., 2002). A typical example is the piracanjuba, Brycon orbignyanus (Valenciennes, 1850), an herbivorous species the diet of which consists almost exclusively of fruits of the gallery forest. The piracanjuba is now nearly extinct in rivers of the State of São Paulo as a consequence of its sensitivity to disturbances such as pollution, deforestation, and lack of adequate food (Barrela et al., 2001). Similarly, the piabanha, Brycon insignis Steindachner, 1876 , which was formerly common, today is represented by a few small stocks in certain affluents in Rio de Janeiro, and is nearly extinct in the São Paulo stretch of the Paraíba do Sul River (Andrade-Talmelli et al., 1999).

Conservation of a particular aquatic biological resource requires knowledge of ecological, physiological, and behavioural variables, which are important to define how a population survives and reproduces in different environments (Hilsdorf and Petrere Jr., 2002).

The objective of the present study was to analyze the seasonal and local reproduction of the Pirapitinga do Sul, Brycon opalinus, in three rivers of the Santa Virgínia Unit of the Serra do Mar State Park. It was possible to determine the areas of greatest breeding intensity, fecundity, and the mode of reproduction, elucidating important aspects for the management and conservation of this species.

\section{Material and Methods}

A total of 12 samples were made monthly from January to December 2004. Each collection period lasted four days. Three sites in the Paraibuna basin were selected for the collections: the Paraibuna, Ipiranga, and Grande rivers. These sites are located within the Santa Virgínia Unit of the Serra do Mar State Park (23 24', $23^{\circ} 17^{\prime} \mathrm{S}$ and $\left.45^{\circ} 03^{\prime} \mathrm{W}\right)$. At each sample point, individuals were collected using gill nets with mesh sizes of $1.5 ; 2.0 ; 2.5 ; 3.0 ; 3.5$, and $4.0 \mathrm{~cm}$, measured between adjacent knots (10 $\mathrm{m}$ long and $1.5 \mathrm{~m}$ high), and totalizing 60 meters. In addition to the nets, sieves and traps were also used.

Fish effort was standardized, keeping time and the quantity of instruments employed at each point constant. Afterwards, specimens were put in plastic containers containing $10 \%$ formalin. Each container was labeled with the date and sample site.

Fishes were identified in the laboratory by specific level. Each individual was measured: total length (millimeters), standard length (millimeters), total mass (grams), sex, and gonad maturation stage (Braga, 1990).

The maturation stage of each specimen was determined macroscopically, considering coloration, transparency, superficial vascularization, and, for ovaries, the visualization and appearance of the oocytes. In agreement to a previously established scale, four different maturation stages were considered: A: immature, B: in maturation, C: mature, and D: spent (Vazzoler, 1996).

The reproductive period was analyzed according to the variation of the frequencies of the different maturation stages during the collecting periods and sample sites.

$L_{50}$ and $L_{100}$ were estimated according to Vazzoler (1996). The $L_{50}$ is the mean length of the first gonad maturation at which $50 \%$ of the individuals are adult, in other words, individuals that have begun the reproductive cycle. The length at which all individuals are apt for reproduction is represented by $L_{100}$.

Fecundity was estimated according to the volumetric method (Vazzoler, 1996). Spawning type was estimated by graphing the data for oocyte diameters and the frequency. Spawning may be single, total, multiple, or intermittent, depending on the variations in the frequencies of the dissociated oocytes. Once the individual fecundity was established for Brycon opalinus, we also estimated the relative fecundity in relation to length $(F R L)$ and in relation to weight $(F R W)$.

\section{Results}

During the collecting period, 266 specimens of B. opalinus in three sites were sampled.

The sex-ratio always tended toward females: at all three collection locales, females were always more numerous than males (Figure 1).

In the Paraibuna River only in June and November did this not occur, with immatures present in January and December (summer). In the Ipiranga River, the highest number of males and females were found in March and April. The highest incidence of immature individuals occurred in the Ipiranga River, mainly in January and March (summer). The fewest specimens were collected in the Grande River, though always with females predominating (Figure 2).

Mature individuals (stage $\mathrm{C}$ ) occurred in all the collections, except in December. Spent individuals (stage D) 
occurred in March, April, and August through December (Figure 3).

In the Paraibuna River, spent individuals occurred mainly in September through December (late winter and spring), and were also present in March and April (late summer and autumn). In the Ipiranga River, spent individuals were found mainly in March and April (late

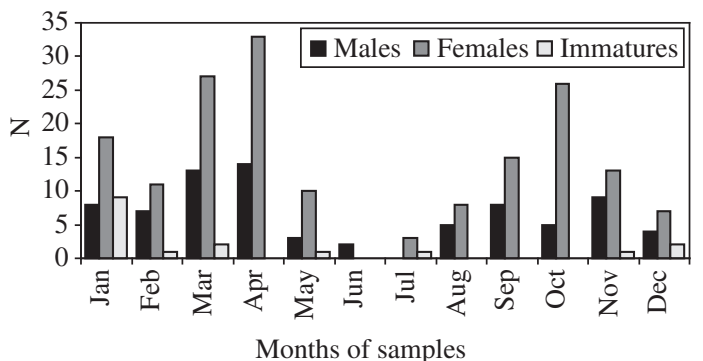

Figure 1. Numerical distribution of Brycon opalinus by sex, in each period of sample.
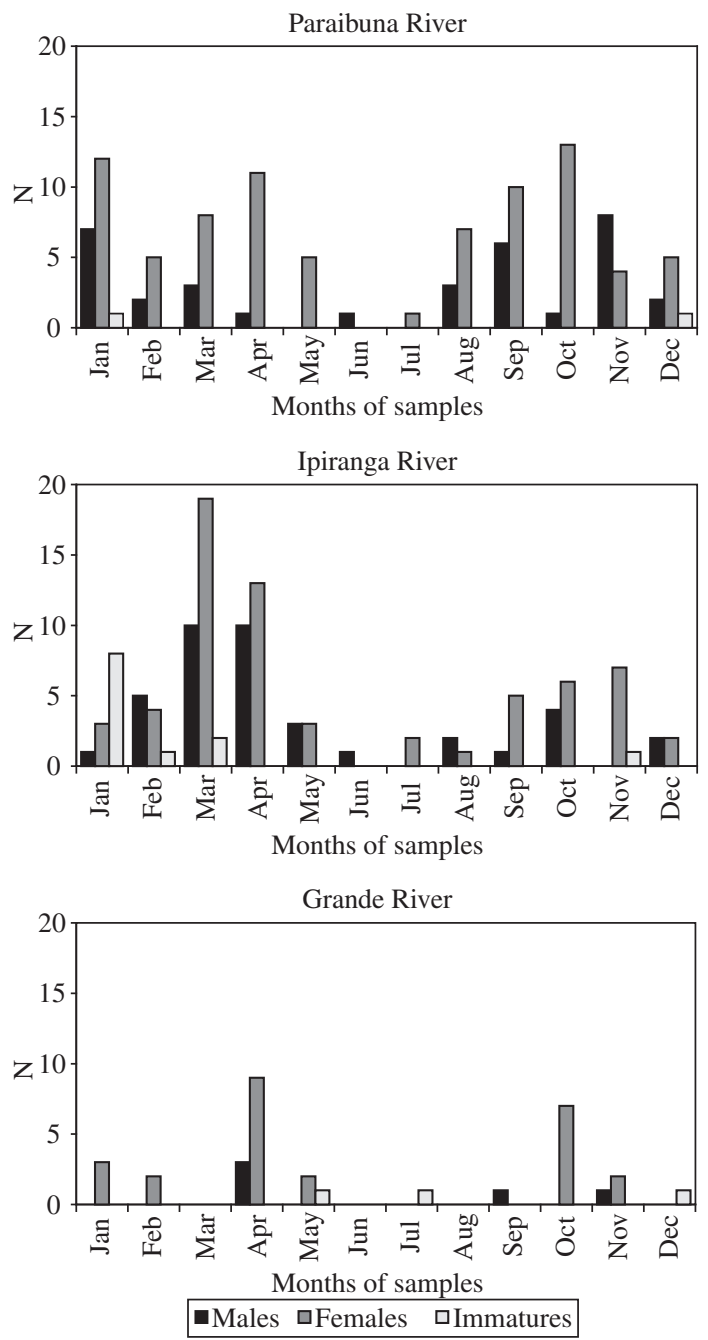

Figure 2. Numerical distribution of Brycon opalinus by sex, in each period and site samples. summer and autumn), and also in August and October through December (late winter and spring). Also in this river, the largest catch of specimens in stage A (immatures) was made in January (summer). In the Grande River, most of the mature individuals occurred in April and October (Figure 4).

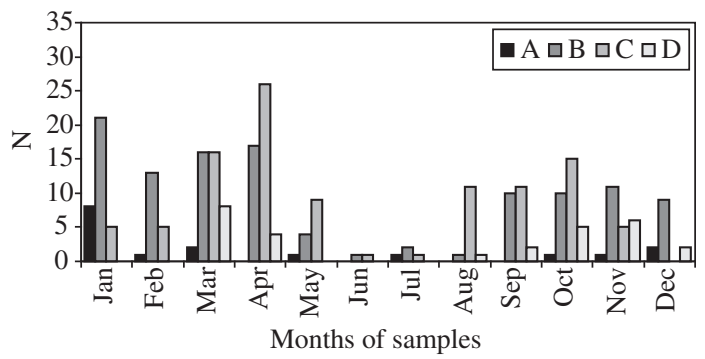

Figure 3. Numerical distribution of Brycon opalinus in the stages of gonadal maturity (a) immature; b) in maturation; c) mature and d) spent) in each period of sample.
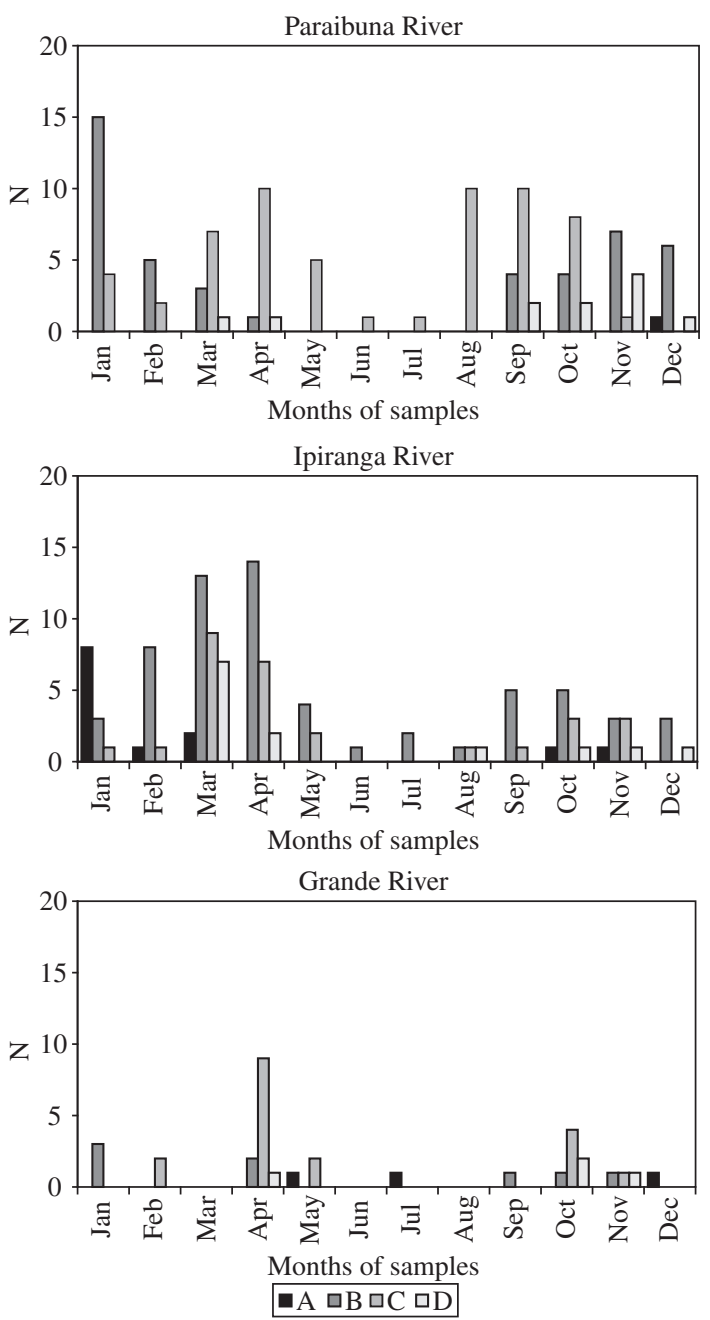

Figure 4. Numerical distribution of Brycon opalinus in the stages of gonadal maturity (a) immature; b) in maturation; c) mature and d) spent) in each period and site samples. 
The $L_{50}$ and $L_{100}$ of $B$. opalinus were about 16 to $18 \mathrm{~cm}$ and 26 to $28 \mathrm{~cm}$, respectively, for males as well as for females, although females tended to mature at a length greater than that of males (Figure 5).

The total number of oocytes $\left(\mathrm{N}^{\prime}\right)$ of the 68 pairs of ovaries analyzed from Pirapitinga do Sul varied from 19,300 to 152,500 oocytes, with a mean of $80,736.03 \pm 3,916.5$ (SE). This number does not correspond to the fecundity, because it includes oocytes in the stock lot, in the process of maturation, and mature oocytes. The fecundity $(\mathrm{N})$ of $B$. opalinus varied from 579 to 28,776 oocytes, with a mean of $9,190.5 \pm 770.23$ (SE). The mean FRL (fecundity relative to length) was $31 \pm 2.38$ (SE), and the mean FRW (fecundity relative to weight) was $31.26 \pm 1.83$ (SE) (Table 1).

The groups of frequency of occurrence by size (diameter) class of oocytes indicated that total spawning was occurring. The oocytes matured at a size of 1,346.4 $\mu \mathrm{m}$, reaching their maximum at $2,509.2 \mu \mathrm{m}$. The stock lot included oocytes from $61.2 \mu \mathrm{m}$ to $367.2 \mu \mathrm{m}$. Grouping the
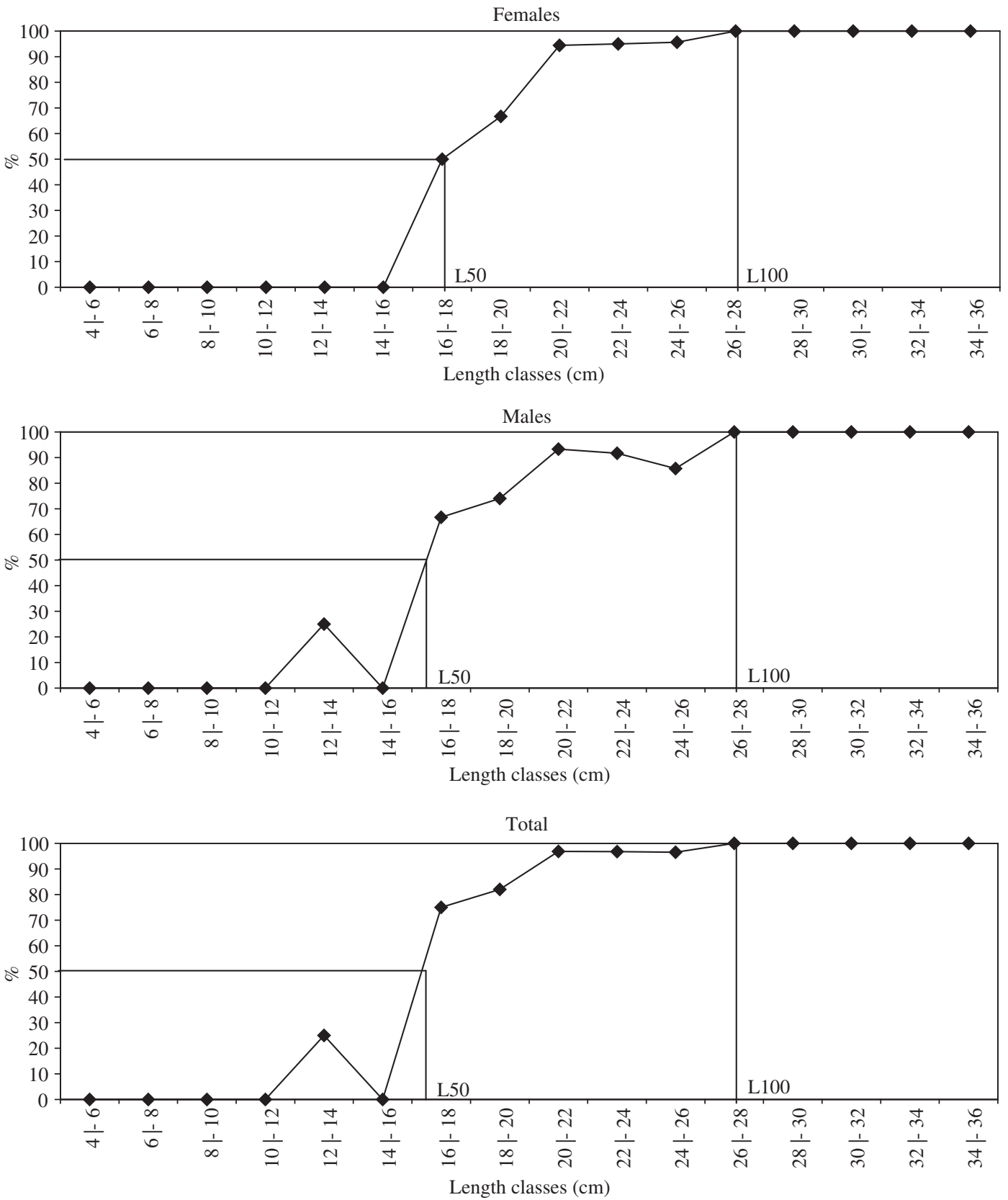

Figure 5. $L_{50}$ and $L_{100}$ of Brycon opalinus for females, males and total. 
Table 1. Total length (TL), total weight (TW), total number of oocytes (N'), number of developing and mature oocytes (N), fecundity in relation to length (FRL), and fecundity in relation to weight (FRW) of the individuals of Brycon opalinus from which the ovaries were analyzed.

\begin{tabular}{|c|c|c|c|c|c|}
\hline TL (mm) & TW (g) & $\mathbf{N}^{\prime}$ & $\mathbf{N}$ & FRL & FRW \\
\hline 291 & 283 & 68,100 & 681 & 2.3 & 2.4 \\
\hline 310 & 339 & 85,200 & 14,484 & 46.72 & 42.72 \\
\hline 304 & 315 & 64,100 & - & - & - \\
\hline 293 & 270 & 69,800 & - & - & - \\
\hline 300 & 287 & 49,400 & - & - & - \\
\hline 305 & 328 & 122,200 & - & - & - \\
\hline 319 & 365 & 93,600 & 3,744 & 11.73 & 10.25 \\
\hline 297 & 306 & 121,100 & - & - & - \\
\hline 340 & 430 & 80,800 & - & - & - \\
\hline 298 & 280 & 70,200 & - & - & - \\
\hline 248 & 156 & 57,100 & 2,284 & 9.2 & 14.64 \\
\hline 224 & 119 & 41,100 & 822 & 3.66 & 6.9 \\
\hline 242 & 146 & 42,200 & 2,110 & 8.71 & 14.45 \\
\hline 345 & 455 & 101,100 & 17,187 & 49.81 & 37.77 \\
\hline 328 & 379 & 141,600 & 11,328 & 34.53 & 29.88 \\
\hline 330 & 388 & 118,800 & 4,752 & 14.4 & 12.24 \\
\hline 311 & 356 & 73,200 & 4,392 & 14.12 & 12.33 \\
\hline 310 & 336 & 102,300 & 6,138 & 19.88 & 18.26 \\
\hline 298 & 291 & 113,800 & 5,690 & 19.09 & 19.55 \\
\hline 259 & 166 & 59,300 & 3,558 & 13.73 & 21.43 \\
\hline 300 & 349 & 120,600 & 12,060 & 40.2 & 34.55 \\
\hline 313 & 348 & 130,700 & 14,377 & 45.93 & 41.31 \\
\hline 218 & 114 & 38,100 & 1,905 & 8.73 & 16.71 \\
\hline 306 & 329 & 121,200 & 14,544 & 47.52 & 44.2 \\
\hline 321 & 427 & 147,250 & 20,615 & 64.22 & 48.27 \\
\hline 334 & 441 & 130,800 & 28,776 & 86.15 & 65.25 \\
\hline 264 & 203 & 63,700 & 4,459 & 16.89 & 21.96 \\
\hline 298 & 314 & 117,200 & 8,204 & 27.53 & 26.12 \\
\hline 266 & 180 & 54,000 & 3,780 & 14.21 & 21 \\
\hline 277 & 255 & 97,400 & 12,662 & 45.71 & 49.65 \\
\hline 350 & 501 & 128,000 & 10,240 & 29.25 & 20.43 \\
\hline 321 & 380 & 101,500 & 10,150 & 31.61 & 26.71 \\
\hline 304 & 284 & 127,100 & 13,981 & 45.99 & 49.22 \\
\hline 289 & 280 & 69,400 & 8,328 & 28.81 & 29.74 \\
\hline 193 & 116 & 46,400 & 1,392 & 7.21 & 12 \\
\hline 212 & 100 & 31,400 & 628 & 2.96 & 6.28 \\
\hline 354 & 486 & 152,500 & 19,825 & 56 & 40.79 \\
\hline 338 & 469 & 140,200 & 16,824 & 49.77 & 35.87 \\
\hline 295 & 300 & 36,900 & 9,225 & 31.27 & 30.75 \\
\hline 300 & 296 & 75,200 & 15,040 & 50.13 & 50.81 \\
\hline 328 & 378 & 75,500 & 12,835 & 39.13 & 33.95 \\
\hline 334 & 412 & 93,700 & 10,307 & 30.85 & 25.01 \\
\hline 285 & 268 & 56,400 & 10,152 & 35.62 & 37.88 \\
\hline 302 & 280 & 59,300 & 11,267 & 37.30 & 40.23 \\
\hline 311 & 314 & 69,700 & 11,849 & 38.09 & 37.73 \\
\hline 225 & 131 & 45,900 & 5,049 & 22.44 & 38.54 \\
\hline 238 & 151 & 46,200 & 5,082 & 21.35 & 33.65 \\
\hline 251 & 169 & 58,200 & 6,984 & 27.82 & 41.32 \\
\hline 330 & 465 & 94,500 & 16,065 & 48.68 & 34.54 \\
\hline 312 & 416 & 97,500 & 17,550 & 56.25 & 42.18 \\
\hline
\end{tabular}


Table 1. Continued...

\begin{tabular}{crrrrr}
\hline TL $(\mathbf{m m})$ & TW $(\mathbf{g})$ & $\mathbf{N}$ & $\mathbf{N}$ & FRL & FRW \\
\hline 273 & 225 & 72,800 & 13,104 & 48 & 58.24 \\
263 & 301 & 74,000 & 15,540 & 59.08 & 51.62 \\
205 & 80 & 19,300 & 579 & 2.82 & 7.23 \\
319 & 367 & 101,800 & 10,180 & 31.91 & 27.73 \\
296 & 304 & 94,800 & 14,220 & 48.04 & 46.77 \\
287 & 260 & 96,200 & 11,544 & 40.22 & 44.4 \\
243 & 173 & 48,100 & 6,253 & 25.73 & 36.14 \\
251 & 175 & 48,800 & 2,928 & 11.66 & 16.73 \\
249 & 165 & 53,800 & 3,228 & 12.96 & 19.53 \\
238 & 135 & 52,600 & 3,682 & 15.47 & 27.27 \\
254 & 180 & 55,800 & 3,906 & 15.37 & 21.7 \\
353 & 486 & 17,880 & 50.65 & 36.79 \\
302 & 311 & 10,668 & 35.32 & 34.3 \\
262 & 211 & 88,600 & 4,000 & 15.27 & 18.96 \\
268 & 185 & 66,700 & 3,505 & 45.73 & 45.97 \\
296 & 277 & 56,700 & 13,398 & 23.39 & 48.36 \\
237 & 146 & 95,700 & 5,544 & 20.49 & 37.97 \\
202 & 87 & 61,600 & 4,140 & & 47.58 \\
\hline
\end{tabular}

stage D (spent) ovaries showed that most oocytes over $1,346.4 \mu \mathrm{m}$ were eliminated, and few were still found in these ovaries (Figure 6).

\section{Discussion}

Predominance of females over males seems to be a natural characteristic of Brycon opalinus. According to Vazzoler (1996), mortality and differential growth can act unequally on males and females, and in other cases, the behaviour of the individuals during a life-cycle event can determine the predominance of one of the sexes, for example the formation of schools of males or females outside the breeding season. However, this does not occur in B. opalinus, because females predominated in every period.

The relatively large catch of immature specimens in the Ipiranga River in January through March, besides indicating the post-spawning period, also showed the importance of this site for breeding, shelter, and feeding of B. opalinus young. In the Pantanal, Brycon microlepis (Perugia, 1897) depends on the flooded areas for breeding (Mateus and Estupiñán, 2002). Conditions in the spawning season must be favorable for the survival and growth of the young, because of the availability of dissolved oxygen, adequate food for the initial developmental phases, and minimizing the risks of predation on the young (Vazzoler, 1996).

Temperature cannot be a limiting factor in the reproduction of Brycon opalinus. Individuals in stage D (spent) were caught as much in the spring and summer (relatively high temperatures) as in autumn (lower temperatures), therefore they showed two reproductive peaks. For fish populations in tropical waters where the temperatures do not limit spawning, seasonality is imposed by environmental factors which lead to the input of nutrients, and by biotic pressures such as competition for spawning grounds or living space (Lowe-McConnell, 1999). Reproductive seasonality is controlled by the availability of foods for young and adults, by interspecies competition for food between the young, and by breeding sites (Kramer, 1978b). This seasonality is either a mechanism for reproductive isolation or has no relationship to local conditions, but signifies the evolution of reproductive specializations that only occur under special conditions (Kramer, 1978a).

Previously published data on reproductive aspects of species of Brycon are summarized in Table 2.

Spring and summer are the preponderant breeding seasons, except for Brycon petrosus Meek and Hildebrand, 1913 (Panama), which breeds in winter, and B. opalinus in the Núcleo Santa Virgínia, which showed two peaks, one in spring/summer and the other in autumn. Individuals in stage $\mathrm{C}$ (mature) were frequent in the entire period, except in June and July (winter), in the Paraibuna river as well as in the Ipiranga river. The reproductive seasonality of $B$. opalinus is of the long type (7 to 9 months), rather than seasonal. The spatial distribution of the spawning areas determines the distance traveled as well as the periodicity of the movements of the fishes; species which live in short rivers have short compact migrations (Lowe-McConnell, 1999). Because of these factors, Brycon opalinus fits the definition of fishes which have external fertilization, are nonmigratory, and lack parental care of the young (Vazzoler, 1996).

The length at first gonadal maturation depends on the manner in which the species exploits food sources, and their availability. In addition to interspecific variations, it shows intraspecific variations as a function of environmental conditions. Therefore, temperature variations and food availability, for example, can influence the length as well 

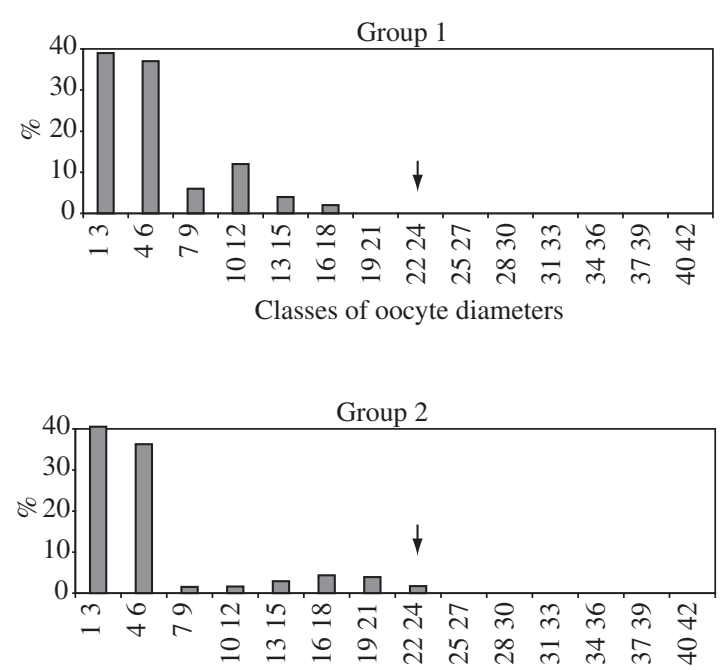

Classes of oocyte diameters
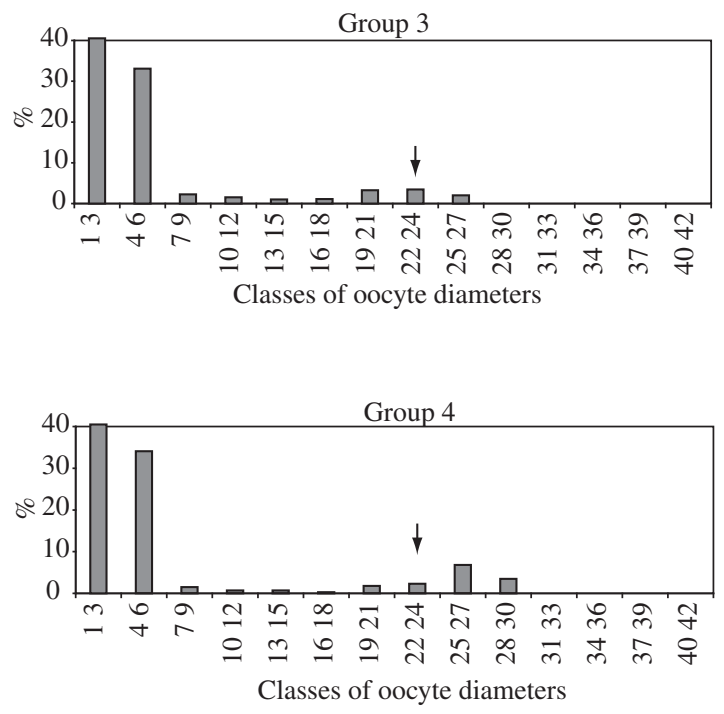
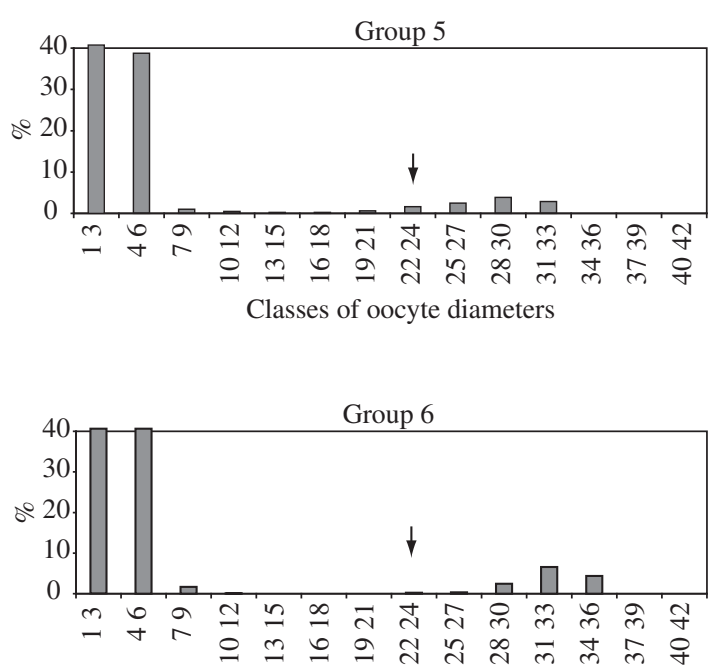

Classes of oocyte diameters
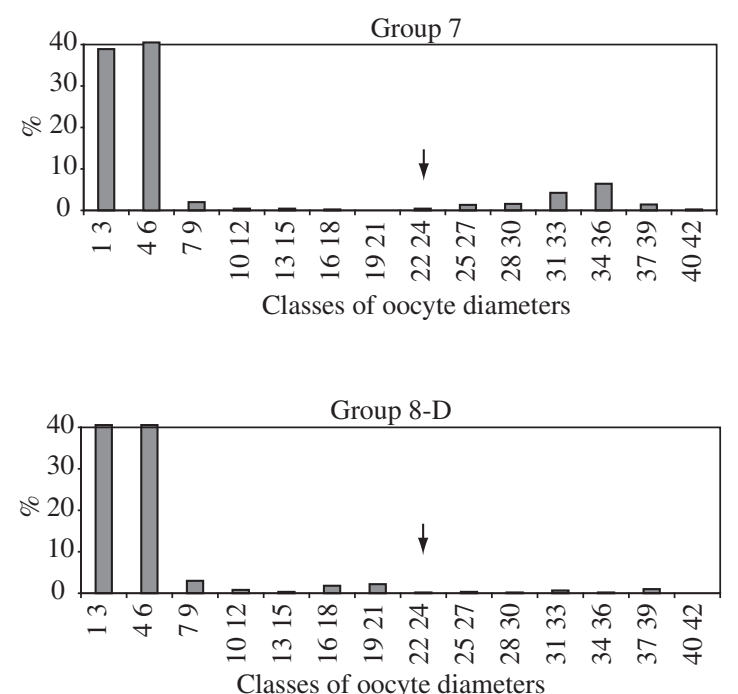

Classes of oocyte diameters

Figure 6. Frequency (in percentage) of the diametrical classes of oocytes, in d.o.m. (division of ocular micrometer) equivalent to 61.2 micrometer, of Brycon opalinus divided into groups (1-7: Groups of ovaries in increasing maturation stages of the oocytes, and 8: Group of spent ovaries.) Arrows indicate the size above which the oocytes become mature.

as the age at first maturation. Knowledge of the population parameters $L_{50}$ and $L_{100}$ is of fundamental importance for rational administration of the fish stocks, because it is an essential element in fixing the minimum possible catch sizes and in determining the mesh sizes of nets, not only for the species of commercial interest, but also for all the species which are caught in the nets (Vazzoler, 1996). These parameters are of utmost importance for the management of a sport or commercial fishery, even more so when dealing with a threatened species which lives not only within the Núcleo Santa Virgínia, where it is protected, but also in areas where fishing occurs.

A very important factor in the reproduction of fishes is fecundity; from knowledge of this parameter it is possible to determine the type and intensity of spawn- ing. The fecundity of $B$. opalinus is relatively low compared to that of Brycon cephalus (Günther, 1869), which is 85,000 oocytes, and of Brycon insignis, which is 24,690 oocytes (Table 2). Both of these species are larger than B. opalinus, which may account for part of this difference. Fecundity is a specific adaptation to variable conditions, especially for mortality, which varies primarily in response to food supply, and is one of the basic means of adjusting the reproductive rate to changing conditions. This parameter also reveals adaptive variation in the population, between populations, and between species, reflecting different conditions of life. Fecundity generally increases in proportion to the weight of the fish, therefore to the cube of the length, thus the larger 
Table 2. Data from the literature and from the present investigation, on reproductive aspects of species of Brycon.

\begin{tabular}{|c|c|c|c|c|c|c|c|}
\hline Authors & $\begin{array}{c}\text { Species } \\
\text { (condition) }\end{array}$ & $\begin{array}{l}\text { Breeding } \\
\text { season }\end{array}$ & $\begin{array}{l}\text { Color of } \\
\text { oocytes }\end{array}$ & $\begin{array}{l}\text { Spawning } \\
\text { type }\end{array}$ & $\begin{array}{c}\text { Oocyte } \\
\text { development }\end{array}$ & $\begin{array}{c}\text { Diameter of } \\
\text { mature oocytes } \\
(\mu \mathrm{m})\end{array}$ & Fecundity \\
\hline Kramer (1978b) & $\begin{array}{l}\text { B. petrosus } \\
\text { (wild) }\end{array}$ & Winter & Pinkish & - & - & $1,600-1,900$ & - \\
\hline Zaiden (2000) & $\begin{array}{l}\text { B. hilarii } \\
\text { (captive) }\end{array}$ & $\begin{array}{l}\text { Spring } \\
\text { Summer }\end{array}$ & Orange & Total & $\begin{array}{l}\text { Synchronous } \\
\text { in two groups }\end{array}$ & - & - \\
\hline $\begin{array}{l}\text { Romagosa et al. } \\
\text { (2001b) }\end{array}$ & $\begin{array}{l}\text { B. cephalus } \\
\text { (captive) }\end{array}$ & - & Green & - & Synchronous & Mean: 1,010 & - \\
\hline $\begin{array}{l}\text { Zaniboni-Filho } \\
\text { and Resende } \\
\text { (1988) }\end{array}$ & $\begin{array}{l}\text { B. cephalus } \\
\text { (wild) }\end{array}$ & - & Green & Total & $\begin{array}{l}\text { Synchronous } \\
\text { in groups }\end{array}$ & $\begin{array}{l}\text { 616-1,109 } \\
\text { Mean: } 857\end{array}$ & - \\
\hline $\begin{array}{l}\text { Romagosa et al. } \\
\text { (2001a) }\end{array}$ & $\begin{array}{l}\text { B. cephalus } \\
\text { (captive) }\end{array}$ & - & $\begin{array}{l}\text { Green } \\
\text { Gray }\end{array}$ & - & - & $939-1,032$ & 85,000 \\
\hline $\begin{array}{l}\text { Pizango-Paima } \\
\text { et al. (2001) }\end{array}$ & $\begin{array}{l}\text { B. cephalus } \\
\text { (wild) }\end{array}$ & Summer & - & - & - & - & - \\
\hline Vazzoler (1996) & $\begin{array}{l}\text { B. orbignyanus } \\
\text { (wild) }\end{array}$ & Summer & - & Total & - & $1,545.9$ & - \\
\hline Zaiden (1997) & $\begin{array}{l}\text { B. orbignyanus } \\
\text { (captive) }\end{array}$ & $\begin{array}{l}\text { Spring } \\
\text { Summer }\end{array}$ & - & - & - & - & - \\
\hline Aires et al. (2000) & $\begin{array}{l}\text { B. orbignyanus } \\
\text { (captive) }\end{array}$ & Spring & - & - & - & - & - \\
\hline $\begin{array}{l}\text { Andrade-Talmelli } \\
\text { et al. (1999) }\end{array}$ & $\begin{array}{l}\text { B. insignis } \\
\text { (captive) }\end{array}$ & $\begin{array}{l}\text { Spring } \\
\text { Summer }\end{array}$ & - & - & - & - & - \\
\hline $\begin{array}{l}\text { Andrade-Talmelli } \\
\text { et al. (2001) }\end{array}$ & $\begin{array}{l}\text { B. insignis } \\
\text { (captive) }\end{array}$ & Summer & - & - & - & - & - \\
\hline $\begin{array}{l}\text { Andrade-Talmelli } \\
\text { et al. (2002) }\end{array}$ & $\begin{array}{l}\text { B. insignis } \\
\text { (captive) }\end{array}$ & - & Green & Total & $\begin{array}{l}\text { Synchronous } \\
\text { in groups }\end{array}$ & Mode: 1,250 & 24,690 \\
\hline $\begin{array}{l}\text { Narahara et al. } \\
\text { (2002) }\end{array}$ & $\begin{array}{l}\text { B. opalinus } \\
\text { (captive) }\end{array}$ & - & $\begin{array}{l}\text { Gray } \\
\text { Wine }\end{array}$ & - & - & $\begin{array}{l}\text { 1,650-2,150 } \\
\text { Mode: } 1,900\end{array}$ & - \\
\hline Present work & $\begin{array}{l}\text { B. opalinus } \\
\text { (wild) }\end{array}$ & $\begin{array}{l}\text { Spring } \\
\text { Summer } \\
\text { Autumn }\end{array}$ & Gray & Total & $\begin{array}{l}\text { Synchronous } \\
\text { in two groups }\end{array}$ & $1,346.4-2,509.2$ & $9,190.5$ \\
\hline
\end{tabular}

the female, the more oocytes are produced (Galvani and Coleman, 1998; Lowe-McConnell, 1999).

According to the classification of Vazzoler (1996) the spawning type of Brycon opalinus is synchronous in two groups, in which, in each breeding period, there are two lots of oocytes within the ovaries: a reserve stock of oocytes, and also oocytes which will mature synchronously and will be laid in the breeding period; thus there is total spawning. Total spawning is frequent in Brycon, and in Brycon hilarii (Valenciennes, 1850) is also synchronous in two groups (Table 2).

The size of mature oocytes is quite variable among the species of Brycon, remaining in a range which characterizes species with external fertilization, migratory or non-migratory, and lacking parental care (Vazzoler, 1996).

The oocyte color of the Brycon species is variable, and may be an adaptive characteristic for camouflaging the eggs in the spawning site preferred by each species. The eggs of Brycon insignis and Brycon petrosus are spherical, demersal, and non-adhesive (Andrade-Talmelli et al., 2002; Kramer, 1978b, respectively), which appears to be the usual case in this genus.

In general, the embryonic development of Brycon is rapid compared to other species of freshwater South American teleost fishes (Kramer, 1978b; Romagosa et al., 2001b).

The presence of the Pirapitinga do Sul depends in great part on water quality (low turbidity and high dissolved oxygen content), and on the preservation of the riverine forests which prevents silting of the riverbeds and supplies food. This close environmental relationship determines the lack of a long breeding migration (piracema); there are only local movements, to access the best areas for the initial development of eggs and larvae. Maintenance of water quality and the riverine forests of these sites is a sine qua non for preservation of this species.

Those species with a limited area of occurrence, with only one or a few small populations with little genetic 
variability, which require special niches in stable environments, are highly vulnerable to extinction (Primack and Rodrigues, 2001).

Acknowledgments - The authors wish to thank FAPESP (proc. 03/05696-1) for financial support, Cotec (proc. 40.673/03), IBAMA (aut. 055/2003), and especially Mr. J. P. Villani (Director of the Núcleo Santa Virgínia-PESM) for making it possible to carry out this research.

\section{References}

AIRES, ED., STEFANINI, MA. and ORSI, AM., 2000. Características ultra-estruturais e diferenciativas das espermátides de piracanjuba (Brycon orbignyanus) durante a espermiogênese. Braz. J. Vet. Res. Anim. Sci., vol. 37, no. 3, p. 01-09.

ANDRADE-TALMELLI, EF., FENERICH-VERANI, N. and VERANI, JR., 1999. Fator de condição relativo (Kn): um critério para selecionar fêmeas de piabanha, Brycon insignis, para indução reprodutiva. Bol. Inst. Pesca, vol. 25, p. 95-99.

ANDRADE-TALMELLI, EF., KAVAMOTO, EM. and FENERICH-VERANI, N., 2001. Características seminais da piabanha, Brycon insignis (Steindachner, 1876), após estimulação hormonal. Bol. Inst. Pesca, vol. 27, no. 2, p. 149-154.

ANDRADE-TALMELLI, EF., KAVAMOTO, EM., NARAHARA, MY. and FENERICH-VERANI, N., 2002. Reprodução induzida da piabanha, Brycon insignis, mantida em cativeiro. Rev. Bras. Zootec., vol. 31, no. 2, p. 803-811.

BARRELA, W., PETRERE JR., M., SMITH, WS. and MONTAG, LFA., 2001. As relações entre as matas ciliares, os rios e os peixes. In Matas Ciliares. Conservação e recuperação. Eds: Rodrigues e Leitão Filho, Edusp, 320p.

BRAGA, FMS., 1990. Aspectos da reprodução e alimentação de peixes comuns em um trecho do rio Tocantins entre Imperatriz e Estreito, Estados do Maranhão e Tocantins, Brasil. Rev. Bras. Biol., vol. 50, no. 3, p. 547-558.

BUCKUP, PA., 2003. Biodiversidade dos peixes da Mata Atlântica. Disponível em: http://www.bdt.fat.org.br/workshop/ mata.atlantica/SE-S/peixes. [Acesso em: 18.mar.2003].

CIDAlE, A., PIANCA, LG. and HILSDORF, A., 2003. Avaliação do crescimento da pirapitinga do sul (Brycon $c f$. reinhardt) em condições de criação de trutas no município de Pindamonhangaba. Disponível em: http://www.unitau.br/prppg/ inicient/iieic/anaisbi2.htm. [Acesso em: 12.mar.2003].

GALVANI, AP. and COLEMAN, RM., 1998. Do parental convict cichlids of different sizes value the same brood number equally? Animal Behaviour, vol. 56, p. 541-546.

GÉRY, J. and MAHNERT, V., 1992. Notes sur quelques Brycon des bassins de 1'Amazone, du Parana-Paraguay et du Sud-Est brésilien. Revue Suisse Zool., vol. 99, no. 4, p. 793-819.

HILSDORF, AWS. and PETRERE JR., M., 2002. Conservação de peixes na bacia do rio Paraíba do Sul. Ciência Hoje, vol. 30, no. 180 , p. $62-65$.
KRAMER, DL., 1978a, Reproductive seasonality in the fishes of a tropical stream. Ecology, vol. 59, no. 5, p. 976-985.

-, 1978b. Terrestrial group spawning of Brycon petrosus in Panamá. Copeia, vol. 1978, no. 3, p. 536-537.

LOWE-MCCONNELL, RH., 1999. Estudos ecológicos de comunidades de peixes tropicais. Tradução de VAZZOLER, AEAM., AGOSTINHO, AA. and CUNNIGHAN, P. São Paulo. Ed. da Universidade de São Paulo. Título original: Ecological studies in tropical fish communities, 535p.

MATEUS, LAF. and ESTUPIÑÁN, GMB., 2002. Fish stock assessment of piraputanga Brycon microlepis in the Cuiabá river basin, pantanal of Mato Grosso, Brazil. Braz. J. Biol., vol. 62, no. 1 , p. $165-170$.

NARAHARA, MY., ANDRADE-TALMELLI, EF., KAVAMOTO, ET. and GODINHO, HM., 2002. Reprodução induzida da pirapitinga do sul, Brycon opalinus, mantida em condições de confinamento. Rev. Bras. Zootec., vol. 31, no. 3, p. 1070-1075.

PIZANGO-PAIMA, EG., PEREIRA-FILHO, M. and OLIVEIRA-PEREIRA, MI., 2001. Composição corporal e alimentar do matrinxã, Brycon cephalus, na Amazônia Central. Acta. Amazônica, vol. 31, no. 3, p. 509-520.

PRIMACK, RB. and RODRIGUES, E., 2001. Biologia da Conservação. Londrina-PR, Ed. Vida, 327p.

ROMAGOSA, E., NARAHARA, MY., BORELLA, MI. and FENERICH-VERANI, N., 2001a. Seleção e caracterização de fêmeas de matrinxã, Brycon cephalus induzidas a reprodução. Bol. Inst. Pesca, vol. 27, no. 2, p. 139-147.

ROMAGOSA, E., NARAHARA, MY. and FENERICHVERANI, N., 2001b. Stages of embryonic development of the "Matrinxã", Brycon cephalus (Pisces, Characidae). Bol. Inst. Pesca, vol. 27, no. 1, p. 29-32.

VAZZOLER, AEAM., 1996. Biologia da reprodução de peixes teleósteos: Teoria e Prática. Maringá-PR, Nupelia, 169p.

VILLANI, JP., SANCHES, RA. and MARETTI, CC., 1998. Plano de manejo das unidades de conservação: Parque Estadual da Serra do Mar-Núcleo Santa Virgínia. Plano de Gestão Ambiental-Fase 1. Secretária do Meio Ambiente, $128 \mathrm{p}$.

ZAIDEN, SF., 1997. Estrutura testicular da piracanjuba Brycon orbignyanus (Valenciennes, 1849) (Pisces, Characidae), nos vários estádios do ciclo sexual. (Dissertação de Mestrado) Centro de Aqüicultura, UNESP, Jaboticabal, SP, 78p.

-, 2000. Morfologia gonadal e metabolismo energético da piraputanga Brycon hilarii (Cuvier e Valenciennes, 1849) (Pisces, Characidae), em cativeiro, durante o ciclo reprodutivo anual. (Tese de Doutorado) - Centro de Aqüicultura, UNESP, Jaboticabal, SP, 152p.

ZANIBONI-FILHO, E. and RESENDE, EK., 1988. Anatomia de gônadas, escala de maturidade e tipo de desova do matrinxã, Brycon cephalus. Rev. Bras. Biol., vol. 48, no. 4, p. 833-844. 
